\title{
Non-timber Forest Products (NTFPs): Contribution towards Farmers' Economy in North-Western Himalayas
}

\author{
Sudhakar Dwivedi ${ }^{1}$, Sunish Sharma ${ }^{2}$, Pawan Kumar Sharma ${ }^{3}$, S.K. Gupta ${ }^{4}$ and \\ M. Iqbal Jeelani Bhat ${ }^{5}$
}

1Associate Professor, Division of Agricultural Economics and Agri-Business Management, SKUAST-Jammu, India 2Ph.D. Scholar, Division of Agricultural Economics and Agri-Business Management, SKUAST-Jammu, India 3Subject Matter Specialist, Krishi Vigyan Kendra, Kathua, SKUAST-Jammu, India 4Professor, Division of Agroforestry, SKUAST-Jammu, India 5Assistant Professor, Division of Statistics \& Computer Science, SKUAST-Jammu, India

*Corresponding author: dwivedi.sudhakar@gmail.com (ORCID ID: 0000-0003-0999-6046)

Received: $14-08-2020$

Revised: $17-11-2020$

Accepted: 06-12-2020

\begin{abstract}
A study was conducted in Rajouri and Kishtwar districts of Jammu region of J\&K to assess the contribution of non-timber forest products (NTFPs) towards farmers' economy in North-Western Himalayas. Anardana and Kalazeera were the important forest NTFPs collected by the farmers of Rajouri and Kishtwar districts, respectively for commercial purpose. Four major blocks of Rajouri namely Doongi, Rajouri, Kalakote and Manjakote and two major blocks of Kishtwar namely Nagseni and Paddar were selected purposively, as the areas earmarked maximum extraction of mentioned NTFPs. Fifteen farmers were selected randomly from each block constituting a sample of 60 farmers from district Rajouri and 30 farmers from district Kishtwar. The average cost of collection of Anardana \& Kalazeera was ₹ 414.16 and ₹ 1106.67, respectively. The overall gross and net income from Anardana was ₹ 7,588.33 and ₹ 5,228.33 per $\mathrm{kg}$ with cost benefit ratio of 3.34. The overall gross and net income from Kalazeera was ₹ 20,566.67 and ₹ 17,863.33 per kg with cost benefit ratio of 7.94. The percentage share of Anardana to total farm income in Rajouri district was 8.99 per cent, whereas it was 49.45 per cent for Kalazeera in Kishtwar district. The overall share of NTFPs to farm income was 24.11 per cent. The farmer's income from NTFPs was significantly determined by total annual household income of the family, total time spent on gathering NTFPs and farm income at 5 per cent level of significance. Non-availability of labour was the major problem reported in collection of Anardana, whereas in case of Kalazeera, difficulty in harvesting the seeds was the major problem. The marketing system and market intelligence for NTFPs is urgently required for optimal use of natural resources and enhancing the income of farmers in North-Western Himalayas.

\section{Highlights}

(0 The percentage share of NTFPs to farm income in Rajouri district was $8.99 \%$ whereas it was $49.45 \%$ in Kishtwar district. The overall share of NTFPs to farm income was $24.11 \%$.

0 A censored regression analysis revealed that farmer's income from NTFPs was significantly determined by total annual household income of the family, total time spent on gathering NTFPs and farm income at $5 \%$ level of significance.
\end{abstract}

Keywords: Non-timber forest products, Anardana, Kalazeera, economics

Indian forests are a huge reservoir of non-timber forest products (NTFPs) such as medicinal and aromatic plants, leaves, fruits, seeds, resins, gums, bamboos, and canes, offer employment that provides up to half the income of about 25 per cent of the country's rural labour force (Theagrajan, 1994).

How to cite this article: Dwivedi, S., Sharma, S., Sharma, P.K., Gupta, S.K. and Bhat, M.I.J. (2020). Non-timber Forest Products (NTFPs): Contribution towards Farmers' Economy in North-Western Himalayas. Economic Affairs, 65(4): 675-680.

Source of Support: None; Conflict of Interest: None 
Economy of J\&K continues to be predominantly agrarian as 49 per cent of the total working force with 42 per cent as cultivators and 7 per cent as agriculture labourers depend directly on agriculture for their livelihood (Economic Survey J\&K, 201415). Conservation of tropical forests, judicious harvesting and processing of NTFPs can enhance rural incomes and can contribute to gross national product without degrading forests (Murali et al. 1996). Tribes of Jammu and Kashmir largely depend upon the forest commodities, which is not only a source of their food supplements, but also a great source of their income generation (Gupta, 2013). Tribes of Rajouri and Kishtwar districts are largely depend upon Non-timber forest based commodities for large part of their income generation and livelihood. Non-timber forest based commodities have provided an important source of food since time immemorial and even in the present scenario; tribe living in this region depend considerably on the Non-timber forest based commodities (Rashid et al. 2007). Anardana (Punica granatum) has been grown over vast tract of the hill slopes of Rajouri district of Jammu and Kashmir and yielded about 158 quintals in 2014-15, which shows its considerable contribution in tribal people's livelihood and income generation (Office of the Divisional Forest Officer Rajouri Forest Division, Rajouri, 2017). The present study was undertaken to assess the contribution of Non-timber forest based products towards farmers' economy in Jammu region of Jammu \& Kashmir.

\section{Methodology}

The present study was conducted in Jammu region of Jammu and Kashmir State. Rajouri and Kishtwar districts were selected purposively having maximum area under Anardana and Kalazeera, respectively. Four blocks namely Manjakote, Rajouri, Doongi and Kalakote were selected from Rajouri district and two blocks namely Nagseni and Paddar were selected from district Kishtwar for collecting primary data on Anardana and Kalazeera, respectively. Further, 15 Anardana and Kalazeera accumulators were selected, randomly from selected blocks of Rajouri and Kishtwar districts.

The primary data were collected through survey method by conducting personal interview of respondents using pretested schedule. The cost and return analysis worked out using cost concepts formulated by Commission for agricultural Costs and prices (CACP).

Tobit Model was used to test the relationship between dependent variable $(\mathrm{Y})$ and explanatory variable $(X)$.

$$
Y=b_{0}+b_{i} X_{i}+U
$$

Where, $Y=$ Percentage share of household income from the sale of Non -Timber forest based products (NTFPs)

$X_{1}=$ Total annual household income of the family (₹); $X_{2}=$ Age of the sample respondents; $X_{3}=$ Education of the sample respondents; $X_{4}=$ Distance travelled from home to forest for gathering NTFPs (Kms); $X_{5}=$ Total time spent on gathering NTFPs (Hrs); $X_{6}=$ Size of the family (No.); $X_{7}=$ Transportation cost (₹); $X_{8}=$ Farm income (₹); $X_{9}=$ Livestock income (₹); $X_{10}$ $=$ Wage income (₹); $X_{11}=$ Income from services and allied activities (₹); $b_{1}$ to $b_{11}=$ Regression Coefficients; $\mathrm{U}$ is error term.

\section{RESULTS AND DISCUSSION}

\section{Occupational status of NTFPs collectors}

The occupational status of NTFPs collectors involved earners, helpers, and dependents in the family. The number of earners, helpers and dependents in different blocks of district Rajouri and Kishtwar are given in Table 1.

The average family size of Anardana collectors in block Rajouri was 79, which included 34 (43.04\%) dependents, followed by 27 (34.18\%) earners and 18 $(22.78 \%)$ helpers. In block Doongi, the family size was 66, including 30 (45.46\%) dependents followed by 22 (33.33\%) earners and 14 (21.21\%) helpers. In block Kalakote, the family size was 70 , which included 31 (44.28\%) earners, 16 (22.86\%) helpers and 23 (32.86\%) dependents. In block Manjakote, the total size of the family was 80 , which included $20(25.00 \%)$ earners, $18(22.50 \%)$ helpers and 42 $(52.50 \%)$ dependents. The family size in Nagseni block of Kishtwar district was 74, which included 34 (45.96\%) dependents and 20 (27.02\%) earners and helpers, whereas in block Paddar, the family size was 70 , which included 17 (24.28\%) earners and helpers and 36 (51.44\%) dependents. Overall, the average size of family in Rajouri district was 4.92, including 1.67 (33.96\%) earners, 1.10 (22.35\%) 
Table 1: Occupational status of different size groups

\begin{tabular}{llllll}
\hline \multicolumn{2}{l}{ Anardana collectors (Rajouri district ) } & & & \\
\hline Particulars & Block & Earners & Helpers & Dependent & Total \\
\hline Economic status & Rajouri $(\mathrm{n}=15)$ & $27(34.18)$ & $18(22.78)$ & $34(43.04)$ & $79(100.00)$ \\
& Doongi $(\mathrm{n}=15)$ & $22(33.33)$ & $14(21.21)$ & $30(45.46)$ & $66(100.00)$ \\
& Kalakote $(\mathrm{n}=15)$ & $31(44.28)$ & $16(22.86)$ & $23(32.86)$ & $70(100.00)$ \\
& Manjakote (n=15) & $20(25.00)$ & $18(22.50)$ & $42(52.50)$ & $80(100.00)$ \\
& Overall & $1.67(33.96)$ & $1.10(22.35)$ & $2.15(43.69)$ & $4.92(100.00)$ \\
\hline Kalazeera collectors (Kishtwar district) & & & & \\
\hline Particulars & Block & Earners & Helpers & Dependent & Total \\
\hline Economic status & Nagseni (n=15) & $20(27.02)$ & $20(27.02)$ & $34(45.96)$ & $74(100.00)$ \\
& Paddar $(\mathrm{n}=15)$ & $17(24.28)$ & $17(24.28)$ & $36(51.44)$ & $70(100.00)$ \\
& Overall & $1.23(25.62)$ & $1.23(25.62)$ & $2.34(48.76)$ & $4.8(100.00)$ \\
\hline
\end{tabular}

Note: Figures in parentheses indicate percentage.

Table 2: Socio-economic variables of farmers collecting NTFPs $(n=90)$

\begin{tabular}{|c|c|c|c|c|c|c|}
\hline \multicolumn{7}{|c|}{ Rajouri district } \\
\hline Particulars & Block & Unit & Minimum & Maximum & Mean & Variance \\
\hline \multirow[t]{5}{*}{ Age } & Rajouri (n=15) & Years & 35 & 60 & 44.40 & 5.26 \\
\hline & Doongi $(n=15)$ & Years & 38 & 60 & 46.93 & 27.21 \\
\hline & Kalakote (n=15) & Years & 34 & 62 & 47.27 & 52.35 \\
\hline & Manjakote (n=15) & Years & 35 & 60 & 45.33 & 35.24 \\
\hline & Total $(\mathrm{n}=60)$ & Years & 34 & 62 & 45.98 & 40.80 \\
\hline \multirow{5}{*}{$\begin{array}{l}\text { Formal } \\
\text { education }\end{array}$} & Rajouri (n=15) & Years & 8 & 24 & 15.22 & 6.24 \\
\hline & Doongi $(n=15)$ & Years & 9 & 19 & 12.66 & 4.8 \\
\hline & Kalakote $(\mathrm{n}=15)$ & Years & 0 & 17 & 14.52 & 4.8 \\
\hline & Manjakote $(\mathrm{n}=15)$ & Years & 10 & 17 & 15.87 & 9.43 \\
\hline & Total $(n=60)$ & Years & 0 & 24 & 18.78 & 18.78 \\
\hline \multirow[t]{5}{*}{ Land holding } & Rajouri (n=15) & hectare & 0.30 & 2.00 & 0.59 & 3.34 \\
\hline & Doongi $(n=15)$ & hectare & 0.15 & 2.50 & 0.52 & 6.83 \\
\hline & Kalakote (n=15) & hectare & 0.15 & 1.50 & 0.43 & 2.04 \\
\hline & Manjakote (n=15) & hectare & 0.25 & 0.60 & 0.39 & 0.18 \\
\hline & Total $(n=60)$ & hectare & 0.15 & 2.50 & 0.48 & 3.06 \\
\hline \multicolumn{7}{|c|}{ Kishtwar district } \\
\hline Particulars & Block & Unit & Minimum & Maximum & Mean & Variance \\
\hline \multirow[t]{3}{*}{ Age } & Nagseni $(\mathrm{n}=15)$ & Years & 32 & 65 & 43.94 & 56.92 \\
\hline & Paddar $(n=15)$ & Years & 33 & 55 & 40.27 & 33.92 \\
\hline & Total $(\mathrm{n}=30)$ & Years & 32 & 65 & 42.1 & 47.33 \\
\hline \multirow{3}{*}{$\begin{array}{l}\text { Formal } \\
\text { education }\end{array}$} & Nagseni (n=15) & Years & 7 & 25 & 14.53 & 26.31 \\
\hline & Paddar (n=15) & Years & 14 & 20 & 17.00 & 34.23 \\
\hline & Total $(n=30$ & Years & 0 & 25 & 17.56 & 39.56 \\
\hline \multirow{3}{*}{ Land holding } & Nagseni (n=15) & hectare & 0.15 & 1.50 & 0.55 & 2.80 \\
\hline & Paddar (n=15) & hectare & 0.15 & 1.50 & 0.40 & 2.04 \\
\hline & Total $(n=30)$ & hectare & 0.15 & 1.50 & 0.47 & 2.44 \\
\hline
\end{tabular}

helpers and 2.15 (43.69\%) dependents. In Kishtwar district, overall, average size of the family was 4.8 with $1.23(25.62 \%)$ earners, 1.23 (25.62\%) helpers and $2.34(48.76 \%)$ dependent.

\section{Socio-economic characteristics of farmers collecting NTFPs}

The descriptive statistics of quantitative socio- economic variables of farmers collecting NTFPs in Rajouri and Kishtwar district has been presented in Table 2. The average age of farmers in district Rajouri was 45.98 years with minimum of 34 years and maximum of 62 years. The average formal education of NTFP collectors was 18.78 years with minimum of 0 and maximum of 24 years. The average size of land holding was 9.63 kanal with 
Table 3: Cost of Anardana collection (Rajouri district)

\begin{tabular}{llllll}
\hline \multirow{2}{*}{$\begin{array}{l}\text { Blocks of district Rajouri (n=60) } \\
\text { Cost of Collection (₹) }\end{array}$} & \multicolumn{4}{c}{$\begin{array}{c}\text { In Rupees (₹) } \\
\text { Cost of Processing }\end{array}$} \\
\cline { 3 - 6 } & & $\begin{array}{l}\text { Cost of Seed } \\
\text { separation }(₹)\end{array}$ & $\begin{array}{l}\text { Cost of Drying } \\
(₹)\end{array}$ & $\begin{array}{l}\text { Cost of grading } \\
(₹)\end{array}$ \\
\hline Rajouri & & 6050.00 & 2100.00 & 150.00 & 750.00 \\
$(\mathrm{n}=15)$ & Total Cost & 140.00 & 10.00 & 50.00 \\
Doongi & Average Cost $/ \mathrm{kg}$ & 403.33 & 1715.00 & 122.50 & 612.50 \\
$(\mathrm{n}=15)$ & Total Cost & 4450.00 & 114.33 & 8.17 & 40.83 \\
Kalakote & Average Cost $/ \mathrm{kg}$ & 296.67 & 1540.00 & 110.00 & 550.00 \\
$(\mathrm{n}=15)$ & Total Cost & 5200.00 & 102.67 & 7.33 & 36.67 \\
Block Manjakote & Average Cost $/ \mathrm{kg}$ & 346.67 & 2030.00 & 145.00 & 725.00 \\
$(\mathrm{n}=15)$ & Total Cost & 9150.00 & 135.33 & 9.67 & 48.33 \\
Total & Average Cost $/ \mathrm{kg}$ & 610.00 & 7385.00 & 527.50 & 2637.50 \\
$(\mathrm{n}=60)$ & Total Cost & 24850.00 & 123.08 & 8.76 & 43.96 \\
\hline
\end{tabular}

Table 4: Cost of Kalazeera collection in Kishtwar district

\begin{tabular}{llllll}
\hline \multirow{2}{*}{$\begin{array}{l}\text { Blocks of district Kishtwar (n=30) } \\
\text { Cost of Collection }(₹)\end{array}$} & \multicolumn{4}{c}{ In Rupees (₹) } \\
\cline { 3 - 6 } & & $\begin{array}{l}\text { Cost of Processing } \\
\text { (₹) }\end{array}$ & 11500.00 & Cost of Drying & Cost of Grading \\
(₹) & 2160.00 & 108.00 & 1332.00 \\
\hline Nagseni & Total Cost & 144.00 & 7.20 & 88.80 \\
$(\mathrm{n}=15)$ & Average Cost $/ \mathrm{kg}$ & 766.67 & 2625.00 & 75.00 & 1050.00 \\
Paddar & Total Cost & 21700.00 & 175.00 & 5.00 & 70.00 \\
$(\mathrm{n}=15)$ & Average Cost $/ \mathrm{kg}$ & 1446.67 & 4785.00 & 183.00 & 2382.00 \\
Total & Total Cost & 33200.00 & 159.50 & 6.10 & 79.40 \\
$(\mathrm{n}=30)$ & Average Cost $/ \mathrm{kg}$ & 1106.67 & &
\end{tabular}

minimum of 3 kanal and maximum of 50 kanal. The table further revealed that in district Kishtwar, the average age of farmers was 42.10 years with minimum of 32 years and maximum of 65 years. The average formal education was 17.56 years with minimum of 0 and maximum of 25 years whereas the average size of land holding was 9.47 kanal with minimum of 3 kanal and maximum of 30 kanal.

\section{Financial assessment of Anardana}

\section{Cost of Anardana collection}

The average cost of collection of Anardana in Rajouri district was ₹ 414.16 which was 84.45 per cent of the total cost involved in Anardana collection. Among all the processing operations, the maximum cost involved in seed separation ( $₹$ 123.08), followed by grading ( $₹ 43.96)$ and drying ( $₹$ 8.76). The share of different cost components in Anardana collection is represented in Fig. 1.

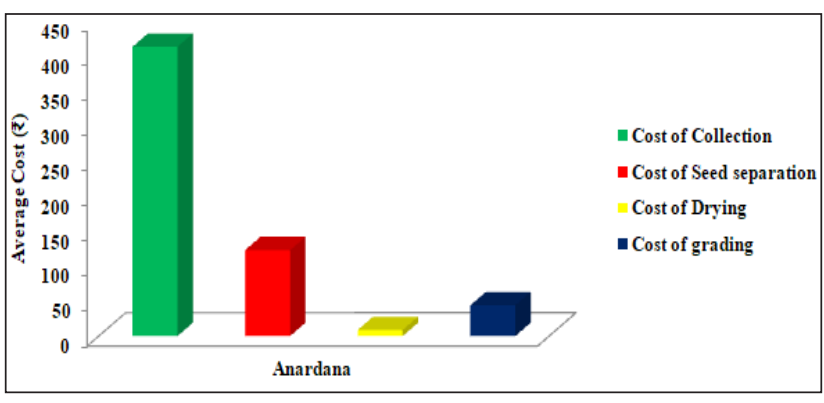

Fig. 1: Financial assessment of Anardana in Rajouri district (₹/kg

\section{Cost of Kalazeera collection}

The average cost of collection of Kalazeera in Kishtwar district was ₹ 1,106.67 (Table 4) Among processing cost of Kalazeera, the maximum cost involved in seed separation ( $₹$ 159.50) followed by grading ( $₹ 79.40)$ and drying (₹ 6.10).

The share of different cost components in Kalazeera collection in Kishtwar district is represented in Fig. 2. 


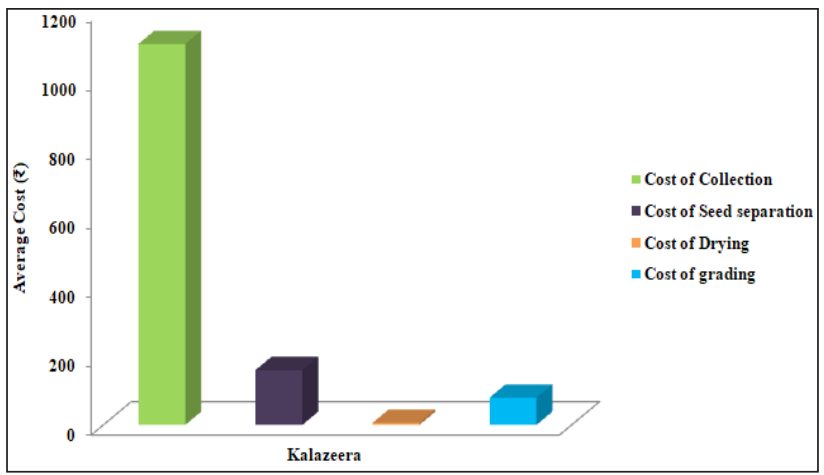

Fig. 2: Financial assessment of Kalazeera in Kishtwar district (₹/kg

The cost $C_{3}$ of Anardana and Kalazeera was $₹ 343.72$ and $₹ 525.58$ respectively. The cost $C_{1}$ and $C_{2}$ was same for both Anardana and Kalazeera which was ₹ 312.48 and ₹ 477.80 , respectively (Table 5).

Table 5: Cost concepts of Anardana and Kalazeera

\begin{tabular}{llll}
\hline \multirow{2}{*}{ S1. No. } & Cost concepts & \multicolumn{2}{c}{ Crops } \\
\cline { 3 - 4 } & & Anardana & Kalazeera \\
\hline 1 & Cost $A_{1}$ & 3.21 & 10.54 \\
2 & $\operatorname{Cost} A_{2}$ & 3.21 & 10.54 \\
3 & $\operatorname{Cost} B_{1}$ & 309.27 & 467.26 \\
4 & $\operatorname{Cost~} B_{2}$ & 309.27 & 467.26 \\
5 & $\operatorname{Cost~} C_{1}$ & 312.48 & 477.80 \\
6 & $\operatorname{Cost} C_{2}$ & 312.48 & 477.80 \\
7 & $\operatorname{Cost} C_{3}$ & 343.72 & 525.58 \\
\hline
\end{tabular}

\section{Returns from Anardana and Kalazeera}

The gross income from Anardana in Rajouri district was ₹ 7,588.33 per $\mathrm{kg}$ and net income was ₹ 5,228.33 (Table 6). The cost benefit ratio was highest in block Rajouri (4.42) followed by block Kalakote (4.18), block Doongi (2.85) and block Manjakote (1.92), whereas the overall cost benefit ratio was 3.34.

Table 6: Returns from Anardana and Kalazeera

\begin{tabular}{lllll}
\hline Blocks & $\begin{array}{l}\text { Gross } \\
\text { Income } \\
\text { (₹) }\end{array}$ & $\begin{array}{l}\text { Total } \\
\text { Cost } \\
\text { (₹) }\end{array}$ & $\begin{array}{l}\text { Net } \\
\text { Income } \\
\text { (₹) }\end{array}$ & $\begin{array}{l}\text { C.B. } \\
\text { Ratio }\end{array}$ \\
\hline Rajouri district & & & & \\
\hline Rajouri (n=15) & 2670.00 & 603.33 & 2066.67 & $1: 4.42$ \\
Doongi (n=15) & 1311.67 & 460.00 & 851.67 & $1: 2.85$ \\
Kalakote (n=15) & 2063.33 & 493.34 & 1569.99 & $1: 4.18$ \\
Manjakote (n=15) & 1543.33 & 803.33 & 740.00 & $1: 1.92$ \\
Total (n=60) & 7588.33 & 2360.00 & 5228.33 & $1: 3.34$ \\
\hline Kishtwar district & & & & \\
\hline Nagseni (n=15) & 9316.67 & 1006.67 & 8310.00 & $1: 9.25$ \\
Paddar $(\mathrm{n}=15)$ & 11,250 & 1696.67 & 9553.33 & $1: 6.63$ \\
\hline Total (n=30) & 20566.67 & 2703.34 & 17863.33 & $1: 7.94$ \\
\hline
\end{tabular}

The gross income from Kalazeera in Kishtwar district was ₹ 20,566.67 per $\mathrm{kg}$ and net income was ₹ 17,863.33 (Table 6). The cost benefit ratio was highest in block Nagseni (9.25) and minimum in block Paddar (6.63). The overall cost benefit ratio of Kalazeera in Kishtwar district was 7.94.

\section{Estimation of factors affecting collection of NTFPs}

$\mathrm{R}$ software was used to estimate the parameters of determinants of the extent of income of farmers from NTFPs and the Tobit regression estimates of determinants are given in Table 7.

Table 7: Tobit regression estimates of determinants of income of farmer from NTFPs

\begin{tabular}{|c|c|c|}
\hline Coefficients & Estimate & Std. Error \\
\hline Intercept & $.577^{*}$ & 0.084 \\
\hline $\begin{array}{l}\text { Total annual household income of } \\
\text { the family (₹) }\end{array}$ & $-0.007^{*}$ & 0.0026 \\
\hline Age of the sample respondents & 0.034 & 0.37 \\
\hline $\begin{array}{l}\text { Education of the sample } \\
\text { respondents (High School) }\end{array}$ & 1.684 & 0.152 \\
\hline $\begin{array}{l}\text { Education of the sample } \\
\text { respondents (middle School) }\end{array}$ & 1.293 & 0.148 \\
\hline $\begin{array}{l}\text { Distance travelled from home to } \\
\text { forest for gathering NTFPs (Kms.) }\end{array}$ & 0.896 & 0.084 \\
\hline $\begin{array}{l}\text { Total time spent on gathering NTFPs } \\
\text { (Hrs.) }\end{array}$ & $1.121^{*}$ & 0.163 \\
\hline Size of the family (No.) & -1.867 & 0.169 \\
\hline Transportation cost $(₹)$ & 0.160 & 0.040 \\
\hline Farm income (₹) & $0.012^{*}$ & 0.004 \\
\hline Livestock income (₹) & -0.003 & 0.0019 \\
\hline Wage income (₹) & -0.041 & 0.0002 \\
\hline $\begin{array}{l}\text { Income from services and allied } \\
\text { activities (₹) }\end{array}$ & -0.043 & 0.0003 \\
\hline $\mathrm{R}^{2}=0.68$ & & \\
\hline
\end{tabular}

The coefficient of determination indicated that 68 per cent of the variation in the income of the farmer by NTFPs is explained by independent variables. The farmer's income from NTFPs was significantly determined by total annual household income of the family, total time spent on gathering NTFPs and farm income at 5 per cent level of significance. Total annual household income of the family was significantly associated with the income of the farmers as it was believed that increasing total annual household income of the family would make a positive effect on farmer's economy. The total time spent on gathering NTFPs was also significantly 
associated with the income of the farmers which means increasing the number of hours for gathering NTFPs would make a positive effect on the farmer's income whereas the increase in farm income would also make a positive effect on farmer's income.

\section{Share of NTFPs in farm income}

Among NTFPs, Anardana (87.72\%) had the maximum contribution to farmer's income followed by Guchi (9.63\%) and Amla (2.27\%) in Rajouri district (Table 8), whereas in Kishtwar district, Kalazeera $(98.12 \%)$ had the maximum contribution to farmer's economy followed by Guchi (1.88\%). The annual income from NTFPs in Rajouri and Kishtwar district was ₹ 1,29,770.00 and ₹ 4,25,250.00, respectively.

Table 8: Share of NTFPs in farm income (Rajouri and Kishtwar)

\begin{tabular}{|c|c|c|c|c|}
\hline $\begin{array}{l}\text { S1. } \\
\text { No. }\end{array}$ & Sources & $\begin{array}{l}\text { Rajouri } \\
\text { district } \\
(\mathrm{n}=60)\end{array}$ & $\begin{array}{l}\text { Kishtwar } \\
\text { district } \\
(\mathrm{n}=30)\end{array}$ & Overall \\
\hline 1 & Anardana & $\begin{array}{l}113825.00 \\
(87.72)\end{array}$ & $\begin{array}{l}0.00 \\
(0.00)\end{array}$ & $\begin{array}{l}113825.00 \\
(20.50)\end{array}$ \\
\hline 2 & Kalazeera & $\begin{array}{l}00.00 \\
(0.00)\end{array}$ & $\begin{array}{l}417250.00 \\
(98.12)\end{array}$ & $\begin{array}{l}417250.00 \\
(75.18)\end{array}$ \\
\hline 3 & Amla & $\begin{array}{l}2950.00 \\
(2.27)\end{array}$ & $\begin{array}{l}0.00 \\
(0.00)\end{array}$ & $\begin{array}{l}2950.00 \\
(0.55)\end{array}$ \\
\hline 4 & Guchii & $\begin{array}{l}12500.00 \\
(9.63)\end{array}$ & $\begin{array}{l}8000.00 \\
(1.88)\end{array}$ & $\begin{array}{l}20500.00 \\
(3.69)\end{array}$ \\
\hline Total & & $\begin{array}{l}129770.00 \\
(100.00)\end{array}$ & $\begin{array}{l}425250.00 \\
(100.00)\end{array}$ & $\begin{array}{l}555020.00 \\
(100.00)\end{array}$ \\
\hline
\end{tabular}

Note: Figures in parentheses indicate percentage.

\section{CONCLUSION}

A study was conducted in Rajouri and Kishtwar district of Jammu and Kashmir state to study the economics of NTFPs, including Anardana in Rajouri and Kalazeera in Kishtwar district. The net income obtained from collection of Anardana and Kalazeera was ₹ 5,288.33/kg and 17,863.33/kg, respectively. Among NTFPs, Anardana (87.72\%) had the maximum contribution in farmer's income followed by Guchi (9.63\%) and Amla (2.27\%) in Rajouri district, whereas in Kishtwar district, Kalazeera (98.12\%) had highest contribution in farmer's economy followed by Guchi (1.88\%). The percentage share of NTFPs to farm income in Rajouri district was 8.99 per cent whereas it was 49.45 per cent in Kishtwar district. The overall share of NTFPs to farm income was 24.11 per cent. A censored regression analysis revealed that farmer's income from NTFPs was significantly determined by total annual household income of the family, total time spent on gathering NTFPs and farm income at 5 per cent level of significance.

\section{REFERENCES}

Economic Survey, 2014-15. Jammu \& Kashmir, Directorate of Economics \& Statistics, Planning and Development Department, Government of Jammu \& Kashmir.

Gupta, S.K., Sharma, O.P., Raina, N.S. and Sehgal, S. 2013. Ethno-Botanical Study of Medicinal Plants of Paddar Valley of Jammu and Kashmir, India. Afr. J. Tradit. Complement Altern. Med., 10(4): 59-65

Murali, K.S., Shankar, U., Shanker, U.R., Ganeshaiah, K.N. and Bawa, K.S. 1996. Extraction of Non-timber forest products in the forests of Biligiri Rangan hills, India. Economic Botany, 50(3): 252-269.

Rashid, A., Anand, V.K. and Serwar, J. 2008. Less Known Wild Edible Plants used by the Gujjar Tribe of District Rajouri, Jammu and Kashmir State. International Journal of Botany, 4: 219-224.

Office of the Divisional Forest Officer, Forest Division, Rajouri, 2017. Preliminary Survey Report.

Theagrajan, K.S. 1994. Non-wood forest products problems and perspectives. My Forest, 30(1): 33-35. 